\title{
Absorption, Plasma Transport, and Cellular Retention of Cobalamin Analogues in the Rabbit
}

\author{
EVIDENCE FOR THE EXISTENCE OF MULTIPLE MECHANISMS THAT \\ PREVENT THE ABSORPTION AND TISSUE DISSEMINATION OF
}

NATURALLY OCCURRING COBALAMIN ANALOGUES

\author{
J. Fred Kolhouse and Robert H. Allen, Division of \\ Hematology-Oncology, Department of Internal Medicine, \\ Washington University School of Medicine, St. Louis, \\ Missouri 63110
}

A B S T R A C T Analogues of cobalamin (Cbl; vitamin $B_{12}$ ) are prevalent in nature as a result of bacterial synthesis, and are of additional interest because of their potential use as antimetabolites and chemotherapeutic agents. We have synthesized $14 \mathrm{Cbl}$ analogues containing ${ }^{57} \mathrm{Co}$ and have compared their gastrointestinal absorption, plasma transport, and cellular retention to that of $\left[{ }^{58} \mathrm{Co}\right] \mathrm{Cbl}$ in rabbits.

Many of the $\mathrm{Cbl}$ analogues were bound with low affinity by intrinsic factor, and none of these $\left[{ }^{57} \mathrm{Co}\right] \mathrm{Cbl}$ analogues were taken up by the ileum or absorbed into the body in amounts comparable to that of $\left[{ }^{58} \mathrm{Co}\right] \mathrm{Cbl}$. The Cbl analogues that were bound by intrinsic factor with high affinity were taken up by the ileum but, in many cases, they were retained there in significant amounts.

Most of the $\mathrm{Cbl}$ analogues were bound by plasma transcobalamin II with high affinity and all of these transcobalamin II- $\left[{ }^{57} \mathrm{Co}\right] \mathrm{Cbl}$ analogue complexes were taken up by a variety of tissues in a manner that was indistinguishable from that of transcobalamin II$\left[{ }^{58} \mathrm{Co}\right] \mathrm{Cbl}$. The few analogues that were bound by transcobalamin II with low affinity were taken up by tissues in lesser amounts, and $20-70 \%$ of these analogues was rapidly excreted in the urine as occurs

This work was presented in part at The Annual Meeting of the American Federation for Clinical Research, Atlantic City, N. J., May 1976. (1)

The present address for Dr. Kolhouse and Dr. Allen is: Division of Hematology, University of Colorado Medical Center, Denver, Colo. 80220.

Received for publication 11 May 1977 and in revised form 3 August 1977. with native $\mathrm{Cbl}$ when it is present in plasma in unbound form.

All of the $\mathrm{Cbl}$ analogues were bound by the granulocyte R-type Cbl-binding protein with high affinity and all of the R-type protein- $\left[{ }^{57} \mathrm{Co}\right] \mathrm{Cbl}$ analogue complexes were cleared rapidly from plasma exclusively by hepatocytes as occurs with R-type protein-[ $\left.{ }^{58} \mathrm{Co}\right] \mathrm{Cbl}$. Some $\mathrm{Cbl}$ analogues were released back into the plasma and were disseminated among a variety of tissues via transcobalamin II as occurs with native $\mathrm{Cbl}$. Other $\mathrm{Cbl}$ analogues were retained in the liver and eventually excreted in the feces and urine without accumulating in other tissues.

These studies indicate that intrinsic factor and the ileum prevent certain $\mathrm{Cbl}$ analogues from entering the body and that the granulocyte R-type protein and hepatocytes prevent the dissemination of certain $\mathrm{Cbl}$ analogues that may gain entry such as during infections with $\mathrm{Cbl}$ analogue-producing bacteria. The fact that transcobalamin II binds and transports a large number of $\mathrm{Cbl}$ analogues indicates that these protective mechanisms can be circumvented and supports the feasibility of using $\mathrm{Cbl}$ analogues as antimetabolites in vivo.

\section{INTRODUCTION}

Cobalamin $\left(\mathrm{Cbl} \text {; vitamin } \mathrm{B}_{12}\right)^{1}$ is synthesized only by microorganisms although man and other animals re-

\footnotetext{
${ }^{1}$ Abbreviations used in this paper: Ade, adenine; BZA, benzimidazole; Cba, cobamide; Cbi, cobinamide; Cbl, cobalamin; CblBP, cobalamin-binding protein; GRP, granulocyte R-type cobalamin-binding protein; IF, intrinsic factor; Me, methyl; NZA, naphthimidazole; TC II, transcobalamin II.
} 
quire 5'-deoxyadenosyl-Cbl and methyl-Cbl as coenzymes for methylmalonyl-CoA mutase and methionine synthetase, respectively (2). Consequently, man and other animals have developed intricate mechanisms for the gastrointestinal absorption and plasma transport of this trace substance (3-5).

Gastric intrinsic factor (IF) binds $\mathrm{Cbl}$ and facilitates its uptake by ileal mucosal cells which contain receptors that specifically bind the IF-Cbl complex but not apo-IF or free $\mathrm{Cbl}(3,6)$. Cbl then enters the ileal mucosal cell and is subsequently released into the portal plasma although the mechanisms involved and the fate of IF are unknown (3-5).

Plasma transcobalamin II (TC II) binds $\mathrm{Cbl}$ and facilitates its uptake by a variety of tissues which contain receptors that specifically bind the TC II-Cbl complex and apo-TC II but not free $\mathrm{Cbl}(7,8)$. The TC II-Cbl complex appears to be taken up by pinocytosis, and after fusion of the pinocytotic vesicles with lysosomes the TC II moiety is degraded $(7,9,10)$. Some of the liberated $\mathrm{Cbl}$ is released from cells $(7,11)$ whereas other molecules are retained and become bound to the two mammalian Cbl-dependent enzymes methylmalonyl-CoA mutase and methionine synthetase $(12,13)$.

Granulocyte R-type Cbl-binding protein (GRP) binds $\mathrm{Cbl}$ and facilitates its uptake exclusively by hepatocytes (14) which contain receptors with specificity for a variety of asialoglycoproteins (15). These receptors bind GRP-Cbl and apo-GRP but not free Cbl (14). Hepatic uptake of the GRP-Cbl complex also appears to involve pinocytosis (15). Some 10-20\% of the GRP-Cbl molecules are excreted intact into the bile by an undefined mechanism whereas the protein moiety of the remaining $80-90 \%$ of the molecules is degraded in lysosomes $(14,15)$. Most of the liberated $\mathrm{Cbl}$ is released back into plasma where it is present bound to TC II although $10-20 \%$ of the liberated $\mathrm{Cbl}$ appears to be retained by hepatocytes and is present bound to methylmalonyl-CoA mutase and methionine synthetase (12).

The possible gastrointestinal absorption and plasma transport of $\mathrm{Cbl}$ analogues is of interest because a variety of $\mathrm{Cbl}$ analogues are synthesized and utilized by bacteria $(2,16)$. The fact that some naturally occurring analogues are inactive (17) and potentially toxic for animals suggests that mechanisms may exist to prevent the absorption and tissue dissemination that could occur from the oral ingestion of analogues, from analogue synthesis by gut flora, and from analogue-producing microorganisms that cross epithelial barriers. The transport of $\mathrm{Cbl}$ analogues is also of interest because of their potential role as antimetabolites-both as cancer chemotherapeutic agents and for studies of the effects of differential inhibition of the two mammalian Cbl-dependent enzymes.
In the present study we have synthesized $14 \mathrm{Cbl}$ analogues and measured their binding and transport by IF, TC II, and GRP in rabbits.

\section{METHODS}

Preparation of $\mathrm{Cbl}$ analogues. The concentration of $\mathrm{Cbl}$ and $\mathrm{Cbl}$ analogues was determined spectrophotometrically at $367.5 \mathrm{~nm}$ in $0.1 \mathrm{M}$ KCN. A molar extinction coefficient of $30,800 / \mathrm{M} \times \mathrm{cm}$ (18) was used in each case except for $\mathrm{CN}-\mathrm{Cbl}[13-\mathrm{epi}]$, for which a value of $20,600 / \mathrm{M}$ $\times \mathrm{cm}$ (19) was used. Descending paper chromatography was performed on Whatman no. 3MM paper at room temperature. The solvent system consisted of $880 \mathrm{ml} \mathrm{sec-butanol,}$ $8.2 \mathrm{ml}$ glacial acetic acid, $6.2 \mathrm{mmol} \mathrm{HCN}$, and a saturating amount ( $\cong 425 \mathrm{ml}$ ) of $\mathrm{H}_{2} \mathrm{O}$.

CN-Cbl was purchased from Sigma Chemical Co., St. Louis, Mo. CN-Cbl[b-OH], CN-Cbl[d-OH], and CN-Cbl[e-OH] were synthesized and isolated as previously described (20) and separated by the method of Yamada and Hogenkamp (21) except that $\mathrm{CN}-\mathrm{Cbl}[\mathrm{d}-\mathrm{OH}]$ was separated from $\mathrm{CN}-\mathrm{Cbl}[\mathrm{e}-\mathrm{OH}]$ by paper chromatography. CN-Cbl[bde-OH] was prepared and purified by chromatography on quartenary aminoethyl (QAE)-Sephadex as previously described (20). CN-Cbl[13-epi] was prepared by the method of Bonnett et al. (19) and purified by paper chromatography. 3,5,6-methylbenzimidazole $\left[3,5,6-\mathrm{Me}_{3} \mathrm{BZA}\right](\mathrm{CN}, \mathrm{OH}) \mathrm{Cba}$ was synthesized by the method of Friedrich and Bernhauer (22) and purified by paper chromatography. [CN,OH]Cobinamide (Cbi) was synthesized by the method of Armitage et al. (23) in which $\mathrm{CN}-\mathrm{Cbl}$ was incubated at $65^{\circ} \mathrm{C}$ for $6 \mathrm{~min}$ in concentrated $\mathrm{HCl}$. The sample was diluted with $10 \mathrm{vol}$ of $\mathrm{H}_{2} \mathrm{O}$, and the chloride was removed by application to a $2.0 \times 30-\mathrm{cm}$ column of Dowex AG $1 \times 8$ acetate, equilibrated in $\mathrm{H}_{2} \mathrm{O}$ at $4^{\circ} \mathrm{C}$. After elution with $0.05 \mathrm{M}$ acetic acid, the sample was lyophilized, dissolved in $\mathrm{H}_{2} \mathrm{O}$, and applied to a $0.7 \times 4.0-\mathrm{cm}$ column of phosphocellulose equilibrated with $0.01 \mathrm{M}$ acetic acid. After washing with four-column volumes of $0.01 \mathrm{~N}$ acetic acid, the sample was eluted with $1 \mathrm{~N} \mathrm{NaCl}$. The salt was removed by phenol extraction (24) and [CN,OH]Cbi was separated from [CN,OH]Cbi-[13-epi] by paper chromatography.

$\mathrm{Cbl}$ analogues with alterations in the base portion were prepared by modification (25) of the biosynthetic technique of Perlman and Barrett (26) using Propionibacterium arabinosum (ATCC 4965). The following respective bases were added to cultures of this bacterium to obtain the following $\mathrm{Cbl}$ analogues: 5,6-dichlorobenzimidazole, $\left[5,6-\mathrm{Cl}_{2} \mathrm{BZA}\right] \mathrm{CN}$ cobamide (Cba); 2,3-diaminonaphthimidazole [NZA]CN-Cba; 3,4 diaminotoluene, [5(6)-MeBZA] CN-Cba; 5(6)-nitrobenzimidazole, $\left[5(6)-\mathrm{NO}_{2} \mathrm{BZA}\right] \mathrm{CN}-\mathrm{Cba}$; benzimidazole, [BZA]CN$\mathrm{Cba}$; 2-methyladenine, [2-MeAde]CN-Cba; and adenine, [Ade]CN-Cba. CN-Cbl was also synthesized in this system by adding 5,6-dimethylbenzimidazole. Bacteria were collected by centrifugation, lysed, and the liberated $\mathrm{Cbl}$ analogues and $\mathrm{Cbl}$ were isolated as described elsewhere (25) using a purification scheme consisting of affinity chromatography on hog non-IF-Sepharose, phenol extraction, and paper chromatography.

Labeled forms of the chemically synthesized $\mathrm{Cbl}$ analogues were prepared on a smaller scale with the same methods described above except that $\mathrm{CN}-\left[^{57} \mathrm{Co}\right] \mathrm{Cbl}$ or $\mathrm{CN}-\left[{ }^{58} \mathrm{Co}\right] \mathrm{Cbl}$ (Amersham/Searle Corp., Arlington Heights, Ill.) was used as the starting material. Inorganic ${ }^{57} \mathrm{Co}$ and ${ }^{58} \mathrm{Co}$ (ICN Pharmaceuticals Inc., Life Sciences Group, Cleveland, Ohio) were added to cultures of $\boldsymbol{P}$. arabinosum to obtain labeled forms of the biosynthetically prepared $\mathrm{Cbl}$ analogues.

Preparation of Cbl-binding proteins. Rabbit stomachs 
(Pel-Freez Bio Animals, Inc., Rogers, Ark.) were homogenized in $10 \mathrm{vol}(\mathrm{vol} / \mathrm{wt}$ ) of $0.15 \mathrm{M} \mathrm{NaCl}, 0.01 \mathrm{M}$ potassium phosphate buffer, $\mathrm{pH} 7.5$, centrifuged at $20,000 \mathrm{~g}$ for $30 \mathrm{~min}$ and the supernate utilized as the source of rabbit IF. Human gastric juice was collected (27) and utilized as the source of human IF. Greater than 95\% of the Cbl-binding activity of both preparations was inhibited by anti-IF-blocking antibody obtained from the serum of a patient with pernicious anemia (27). Rabbit serum, and human serum which had been passed over a column of rabbit anti-human milk R-type protein-Sepharose (28), were utilized as the source of rabbit and human TC II. When portions of both preparations were saturated with $\mathrm{CN}-\left[{ }^{37} \mathrm{Co}\right] \mathrm{Cbl}$ and subjected to gel filtration on Sephadex G-150, $>95 \%$ of the bound $\mathrm{CN}-\left[{ }^{57} \mathrm{Co}\right] \mathrm{Cbl}$ eluted with an apparent mol wt of 40,000. Rabbit (29) and human (30) granulocytes were frozen, sonicated, and centrifuged (30) and the supernates were utilized as the source of rabbit and human GRP. When portions of both preparations were saturated with $\mathrm{CN}-\left[{ }^{57} \mathrm{Co}\right] \mathrm{Cbl}$ and subjected to gel filtration, $>95 \%$ of the bound $\mathrm{CN}-\left[{ }^{57} \mathrm{Co}\right] \mathrm{Cbl}$ eluted with an apparent mol wt of 150,000 . Greater than $95 \%$ of the bound $\mathrm{CN}-\left[{ }^{57} \mathrm{Co}\right] \mathrm{Cbl}$ in both preparations was specifically precipitated by guinea pig anti-human milk R-type protein antiserum in $40 \%\left(\mathrm{NH}_{4}\right)_{2} \mathrm{SO}_{4}$.

Determination of Cbl-binding ability and association constants. Cbl-binding ability was assayed by a modification (27) of the charcoal adsorption method of Gottlieb et al. (31). Samples to be assayed $(0.05-0.2 \mathrm{ml})$ were adjusted to $2.0 \mathrm{ml}$ using $0.1 \mathrm{M}$ potassium phosphate, $\mathrm{pH} 7.5$ containing $1 \mathrm{mg}$ per $\mathrm{ml}$ of bovine serum albumin. $1 \mathrm{ml}$ of $\mathrm{CN}-\left[{ }^{57} \mathrm{Co}\right] \mathrm{Cbl}(1 \mathrm{pmol} / \mathrm{ml}, 10 \mu \mathrm{Ci} / \mu \mathrm{g}$ ) was added and after $30 \mathrm{~min}$ at $37^{\circ} \mathrm{C}, 2.0 \mathrm{ml}$ of bovine serum albumin-coated charcoal was added to adsorb unbound $\mathrm{CN}-\left[{ }^{57} \mathrm{Co}\right] \mathrm{Cbl}$. After standing an additional $15 \mathrm{~min}$, the mixtures were centrifuged at $20,000 \mathrm{~g}$ for $10 \mathrm{~min}$ and $3 \mathrm{ml}$ of supernate was counted in a Beckman Gamma 300 Scintillation counter (Beckman Instruments, Inc., Fullerton, Calif.).

The charcoal adsorption technique just described was used to measure the relative affinities of $\mathrm{Cbl}$ analogues for Cbl-binding proteins (CblBP) by determining the binding of $\mathrm{CN}-\left[{ }^{57} \mathrm{Co}\right] \mathrm{Cbl}$ in the presence of varying concentrations of nonradioactive $\mathrm{CN}-\mathrm{Cbl}$ analogue. Reaction mixtures contained in order of addition: $1.0 \mathrm{pmol}$ of $\mathrm{CN}-\left[{ }^{57} \mathrm{Co}\right] \mathrm{Cbl}$, known amounts of $\mathrm{CN}-\mathrm{Cbl}$ analogues (0.25-100,000 pmol), and 0.5 pmol of Cbl-binding ability, and were incubated at $37^{\circ} \mathrm{C}$ for $10 \mathrm{~min}^{2}$ The ratio of the association constant of $\mathrm{CN}-\mathrm{Cbl}$ analogue, $\left(K_{A} \mathrm{CN}-\mathrm{Cbl}\right.$ analogue), for CblBP to the association constant of $\mathrm{CN}-\mathrm{Cbl},\left(K_{A} \mathrm{CN}-\mathrm{Cbl}\right)$, for CblBP was obtained from the following equation which is derived in the appendix:

$\underline{K_{A} \mathrm{CN} \text {-analogue }}$ $K_{A} \mathrm{CN}-\mathrm{Cbl}$

$$
=\frac{[(\mathrm{CblBP} \text { total })-(\mathrm{CN}-\mathrm{Cbl}-\mathrm{CblBP})][\mathrm{CN}-\mathrm{Cbl}]}{[(\mathrm{CN}-\text { analogue total })-(\mathrm{CblBP} \text { total })} .
$$

\footnotetext{
2 These values may in part represent relative rates of association of $\mathrm{Cbl}$ analogue and native $\mathrm{Cbl}$ since a true equilibrium may not have been achieved during the relatively short time periods utilized for these determinations. This seems unlikely, however, since differences were not observed when incubations were extended to $60 \mathrm{~min}$. Incubations of several days' duration could not be performed due to instability of the protein preparations at $37^{\circ} \mathrm{C}$ under these conditions. In any event, the values obtained appear to be the important ones from a physiologic standpoint.
}

The charcoal adsorption technique was also used to measure the association constant of CN-Cbl for CblBP. The basic technique described above was modified in the following manner: (a) high specific activity $\mathrm{CN}-\left[{ }^{57} \mathrm{Co}\right] \mathrm{Cbl},(200$ $\mu \mathrm{Ci} / \mu \mathrm{g}$ ) was used in amounts ranging from 5 to $100 \mathrm{fmol}$; (b) the amount of CblBP was reduced to $12.5 \mathrm{fmol}$ of Cblbinding ability; $(c)$ the amount of bovine serum albumin was reduced to $25 \mu \mathrm{g} / \mathrm{ml}$; and $(d)$ the incubation time at $37^{\circ} \mathrm{C}$ was increased to $2 \mathrm{~h}$. Double reciprocal plots of $1 / \mathrm{CN}$ $\left[{ }^{57} \mathrm{Co}\right] \mathrm{Cbl}$ free vs. $1 / \mathrm{CN}-\left[{ }^{57} \mathrm{Co}\right] \mathrm{Cbl}$ bound were prepared as described previously (6).

Animal studies. Male New Zealand white rabbits were prepared, injected, and their organs assayed for radioactivity as previously described $(7,14) . \mathrm{CN}-\left[{ }^{57} \mathrm{Co}\right] \mathrm{Cbl}$ analogue $(5 \mathrm{pmol})$ and $\mathrm{CN}-\left[{ }^{58} \mathrm{Co}\right] \mathrm{Cbl}(5 \mathrm{pmol})$ were incubated for $20 \mathrm{~min}$ with a threefold excess of CblBP before injection. Oral administration of $5 \mathrm{pmol}$ of free $\mathrm{CN}-\left[{ }^{57} \mathrm{Co}\right] \mathrm{Cbl}$ analogue mixed with $5 \mathrm{pmol}$ of free $\mathrm{CN}-\left[{ }^{58} \mathrm{Co}\right] \mathrm{Cbl}$ in a final volume of $2 \mathrm{ml}$ of $0.15 \mathrm{M} \mathrm{NaCl}, 0.01 \mathrm{M}$ potassium phosphate, $\mathrm{pH}$ 7.5 , was accomplished with a pediatric nasogastric tube positioned in the stomachs of rabbits who had been fasted for $16 \mathrm{~h}$.

When $\mathrm{CN}-\left[{ }^{57} \mathrm{Co}\right] \mathrm{Cbl}$ and $\mathrm{CN}-\left[{ }^{58} \mathrm{Co}\right] \mathrm{Cbl}$, both obtained from Amersham/Searle Corp., were administered simultaneously the ratios via each of the transport systems obtained in all organs and tissues averaged 1.0 and were never outside the range of 0.8-1.2. Data are presented in general only for heart, lung, kidney, liver, and bowel but $\mathrm{Cbl}$ and $\mathrm{Cbl}$ analogues were also found diffusely distributed in essentially all other organs and tissues. The total body content of radioactive $\mathrm{Cbl}$ and $\mathrm{Cbl}$ analogues plus that excreted in the urine and feces always agreed well with the content of administered radioactivity.

\section{RESULTS}

Synthesis of $\mathrm{Cbl}$ and $\mathrm{Cbl}$ analogues. The structure of $\mathrm{CN}-\mathrm{Cbl}$ and the presumed partial structures of the $14 \mathrm{Cbl}$ analogues are shown in Fig. 1. All of the analogues were synthesized by standard techniques as described under Methods. The structures of the Cbl analogues have been determined previously using a variety of techniques (16) including the ultimate method of X-ray crystallography in some cases. All of the analogues gave single red spots on paper chromatography and their $R_{f}$ values differed from that of $\mathrm{CN}-\mathrm{Cbl}$ as shown in Table I. Single radioactive peaks were obtained with each of the ${ }^{57} \mathrm{Co}$ and ${ }^{58} \mathrm{Co}$ analogues. The $R_{f}$ value for each radioactive analogue was the same as for the corresponding unlabeled analogue.

Affinity of $\mathrm{Cbl}$ and $\mathrm{Cbl}$ analogues for CblBP. The association constant for $\mathrm{CN}-\mathrm{Cbl}$ and each of the rabbit and human CblBP was determined as described under Methods. The order of the association constants for $\mathrm{CN}-\mathrm{Cbl}$ for rabbit CblBP was GRP > TC II > IF with values of 8.0, 2.6, and $0.5 \mathrm{pM}^{-1}$, respectively. The order for human CblBP was GRP > IF > TC II with values of $7.5,1.9$, and $0.5 \mathrm{pM}^{-1}$, respectively.

The affinity of each analogue relative to $\mathrm{CN}-\mathrm{Cbl}$, $\left(K_{A} \mathrm{CN}\right.$-analogue $\left./ K_{A} \mathrm{CN}-\mathrm{Cbl}\right)$, for each of the CblBP was determined by measuring the ability of each analogue to competitively inhibit the binding of 


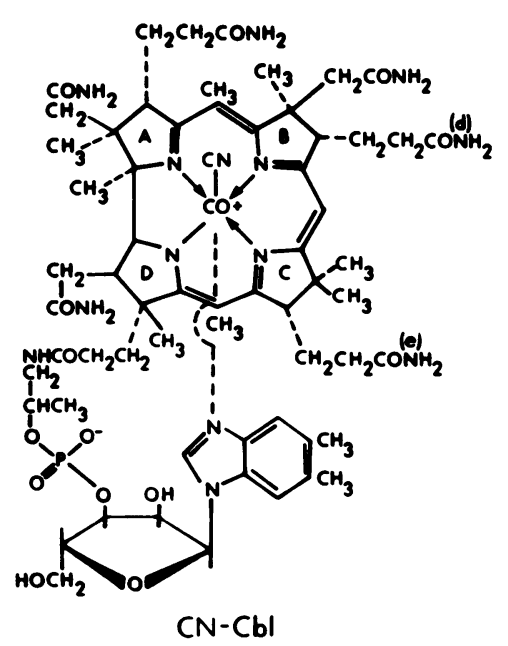

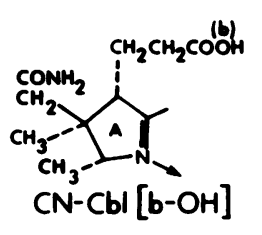

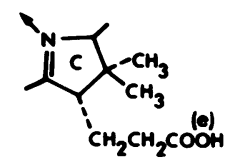

$\mathrm{CN}-\mathrm{Cb}[\mathrm{e}-\mathrm{OH}]$

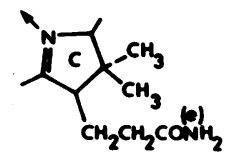

$\mathrm{CN}-\mathrm{Cbl}$ [13-epi]<smiles></smiles>

[NZA]CN-Cbo<smiles>Cn1cnc2ccc([N+](=O)[O-])cc21</smiles>

$\left[5(6)-\mathrm{NO}_{2} \mathrm{BZA}\right] \mathrm{CN}-\mathrm{Cba}$<smiles>Cn1cnc2ncnc(N)c21</smiles>

[2-MeAde]CN-Cbo<smiles></smiles>

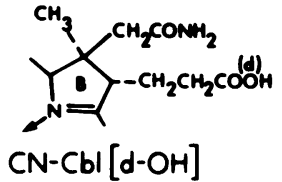

$\mathrm{CN}-\mathrm{Cbl}[$ bde-OH]

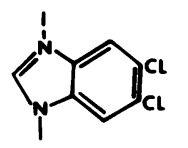

$\left[5,6-\mathrm{Cl}_{2} \mathrm{BZA}\right] \mathrm{CN}-\mathrm{Cbo}$<smiles>Cn1cnc2ccccc21</smiles>

$\left[5(6)-M_{0} B Z A\right] C N-C b a$

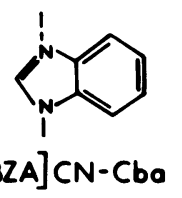<smiles>Cn1cnc2ncnc(N)c21</smiles>

[Ade] $\mathrm{CN}$-Cbo

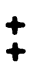

$[\mathrm{CN}, \mathrm{OH}] \mathrm{Cbi}$

$\left[{ }^{57} \mathrm{Co}\right] \mathrm{CN}-\mathrm{Cbl}$. It should be noted that the minimal inhibition observed with some $\mathrm{Cbl}$ analogues could be due to contamination with trace amounts of $\mathrm{CN}$ $\mathrm{Cbl}$ or other $\mathrm{CN}-\mathrm{Cbl}$ analogues. The following internal checks on the appropriateness of the equation utilized to measure $K_{A} \mathrm{CN}$-analogue $/ K_{A} \mathrm{CN}$-Cbl were satisfied for all $14 \mathrm{CN}$-analogues and CN-Cbl: $(a)$ plots of the values resulted in straight lines; $(b)$ the lines passed through the origin; and $(c)$ when nonradioactive $\mathrm{CN}-\mathrm{Cbl}$ was the inhibitor, a value of 1 was obtained. The data obtained with human IF and CN-Cbl[b-OH], CN-Cbl[d-OH], CN-Cbl [e-OH), and CN-Cbl are shown as examples in Fig. 2.

The values of $K_{A} \mathrm{CN}$-analogue/ $K_{A} \mathrm{CN}$-Cbl obtained for the 14 analogues and the 6 CblBP are shown in Table I. They indicate that rabbit and human IF are the most selective CblBP and have relatively low affinities (i.e. $K_{A}$ analogue $/ K_{A} \mathrm{Cbl}<0.01$ ) for analogues missing the $b$ or e or $b, d$, e amino groups, as well as for those in which the BZA portion of the nucleotide moiety has been replaced by a purine, or can not coordinate with the cobalt moiety. Rabbit and human TC II are less selective and have low affinities only for the analogues missing the $\mathrm{b}$ or $\mathrm{b}, \mathrm{d}$, e amino groups and those in which the nucleotide moiety can not coordinate with the cobalt moiety. Rabbit and human GRP are the least selective CblBP and bind all of the analogues studied with relatively high affinity. In contrast to these differences among classes of CblBP differences among corresponding rabbit and human CblBP are much less striking.

Absorption and ileal retention of $\mathrm{CN}-\mathrm{Cbl}$ and $\mathrm{CN}$ Cbl analogues. Previous studies (3-6) have shown that IF-Cbl binds to ileal cell surface receptors. $\mathrm{Cbl}$ then enters the ileal cell and, after a delay of several hours, is released into the portal blood. Fig. 3 contains the results obtained when 5 pmol of unbound [BZA]CN-[ $\left.{ }^{57} \mathrm{Co}\right] \mathrm{Cba}$ and $5 \mathrm{pmol}$ of unbound $\mathrm{CN}-\left[{ }^{58} \mathrm{Co}\right] \mathrm{Cbl}$ were administered orally to rabbits at the same time. The absorption of the analogue was delayed and reduced relative to native $\mathrm{Cbl}$ despite the fact that this analogue and native $\mathrm{Cbl}$ were bound to rabbit IF with the same affinity. After $24 \mathrm{~h}$, the analogue was present in excess of native $\mathrm{Cbl}$ in the ileum which indicates that entry into the ileal cell after binding to ileal receptors, or release into the portal blood from the ileal cell, was delayed.

Table II contains data on the relative absorption and ileal retention of all 14 analogues $24 \mathrm{~h}$ after

FIGURE 1 Structure of $\mathrm{CN}-\mathrm{Cbl}$ and the partial structures of $\mathrm{Cbl}$ analogues showing only those portions of the molecule that differ from $\mathrm{CN}-\mathrm{Cbl}$. *, this analogue contains $\mathrm{OH}$ groups in place of $\mathrm{NH}_{2}$ groups in the $\mathrm{b}, \mathrm{d}$, and e positions; $\$$ this analogue lacks the $\mathrm{PO}_{4}$, ribose, and 5,6-dimethyl-benzimidazole moieties, i.e., the entire nucleotide moiety, of $\mathrm{CN}-\mathrm{Cbl}$. 
TABLE I

Relative Mobility and Affinity of Cbl Analogues for Rabbit and Human CblBP

\begin{tabular}{|c|c|c|c|c|c|c|c|}
\hline \multirow[b]{3}{*}{ Analogue } & \multirow[b]{3}{*}{$R_{f^{*}}$} & \multicolumn{6}{|c|}{$K_{A} \mathrm{CN}$-analogue $/ K_{A} \mathrm{CN}-\mathrm{Cbl}$} \\
\hline & & \multicolumn{3}{|c|}{ Rabbit } & \multicolumn{3}{|c|}{ Human } \\
\hline & & IF & TC II & GRP & IF & TC II & GRP \\
\hline $\mathrm{CN}-\mathrm{Cbl}[\mathrm{b}-\mathrm{OH}]$ & 1.9 & 0.0006 & 0.01 & 0.2 & 0.0006 & 0.006 & 0.1 \\
\hline $\mathrm{CN}-\mathrm{Cbl}[\mathrm{d}-\mathrm{OH}]$ & 1.5 & 0.3 & 0.3 & 0.8 & 0.3 & 0.3 & 0.6 \\
\hline $\mathrm{Cn}-\mathrm{Cbl}[\mathrm{e}-\mathrm{OH}]$ & 1.9 & 0.004 & 0.3 & 0.7 & 0.004 & 0.02 & 0.5 \\
\hline CN-Cbl[bde-OH] & 2.4 & 0.000006 & 0.00009 & 0.04 & 0.000007 & 0.00002 & 0.03 \\
\hline CN-Cbl[13-epi] & 0.7 & 0.8 & 0.8 & 0.9 & 0.8 & 0.7 & 0.5 \\
\hline CN-Cbl & 1.0 & 0.9 & 0.9 & 1.0 & 1.1 & 0.9 & 1.0 \\
\hline$\left[5,6-\mathrm{Cl}_{2} \mathrm{BZA}\right] \mathrm{CN}-\mathrm{Cba}$ & 1.4 & 1.0 & 1.0 & 1.0 & 1.0 & 1.1 & 1.1 \\
\hline$[\mathrm{NZA}] \mathrm{CN}-\mathrm{Cba}$ & 1.2 & 0.05 & 0.8 & 1.0 & 0.1 & 0.3 & 0.6 \\
\hline [5(6)-MeBZA]CN-Cba & 0.8 & 0.8 & 0.9 & 1.0 & 0.8 & 0.9 & 1.0 \\
\hline$\left[5(6)-\mathrm{NO}_{2} \mathrm{BZA}\right] \mathrm{CN}-\mathrm{Cba}$ & 0.7 & 0.1 & 0.6 & 0.8 & 0.07 & 0.3 & 0.5 \\
\hline [BZA]CN-Cba & 0.6 & 1.0 & 1.0 & 0.8 & 0.5 & 0.8 & 0.7 \\
\hline [2-MeAde]CN-Cba & 0.4 & 0.0006 & 0.3 & 0.9 & 0.0005 & 0.05 & 0.7 \\
\hline [Ade]CN-Cba & 0.5 & 0.003 & 0.4 & 0.5 & 0.00007 & 0.1 & 0.1 \\
\hline$\left[3,5,6-\mathrm{Me}_{3} \mathrm{BZA}\right](\mathrm{CN}, \mathrm{OH}) \mathrm{Cba}$ & 1.2 & 0.0007 & 0.0008 & 1.0 & 0.0002 & 0.0002 & 0.2 \\
\hline$[\mathrm{CN}, \mathrm{OH}] \mathrm{Cbi}$ & 1.6 & 0.00006 & 0.0003 & 0.4 & $<0.000001$ & 0.0007 & 0.1 \\
\hline
\end{tabular}

* Mobility relative to $\mathrm{CN}-\mathrm{Cbl}$ on paper chromatography performed as described under Methods.

$\neq \mathrm{CN}$-Cbl produced biosynthetically with $P$. arabinosum.

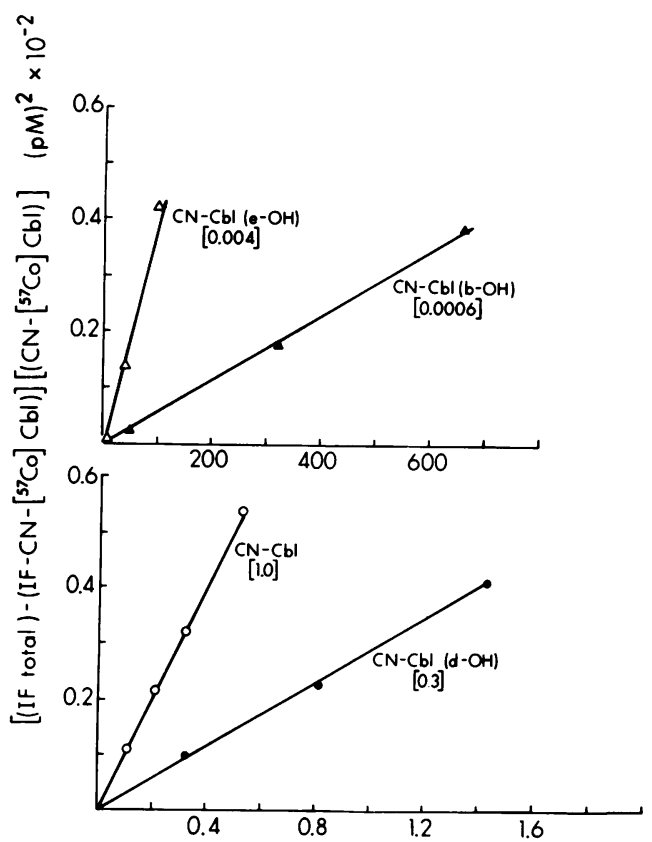

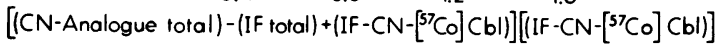

$$
(\mathrm{PM})^{2} \times 10^{-2}
$$

FIGURE 2 Determination of the ratio of $K_{A} \mathrm{CN}$-analogue/ $K_{A} \mathrm{CN}-\mathrm{Cbl}$ for three $\mathrm{Cbl}$ analogues and human IF. The values for the ordinate and abcissa were obtained from the equation derived in the Appendix and were determined as described in Methods. The numbers in brackets are the slopes of the lines and equal $K_{A} \mathrm{CN}$-analogue $/ K_{A} \mathrm{CN}$-Cbl. Values for other analogues and other CblBP are contained in Table I.

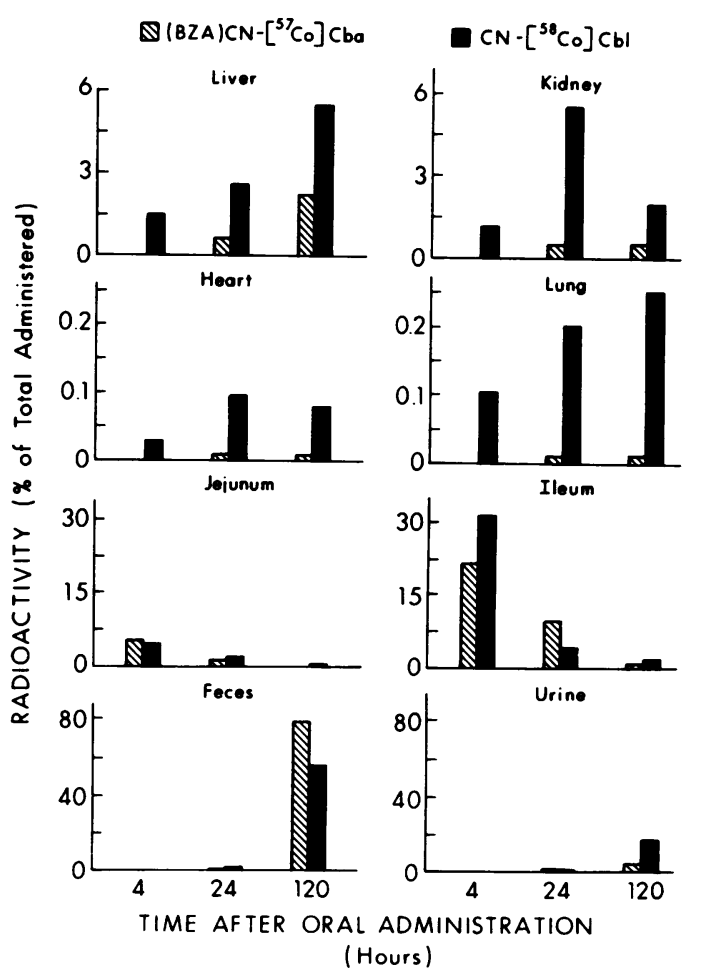

FIGURE 3 Tissue distribution of radioactivity 4, 24, and 120 $h$ after the simultaneous oral administration of 5 pmol of free $[\mathrm{BZA}] \mathrm{CN}-\left[{ }^{57} \mathrm{Co}\right] \mathrm{Cba}$ and $5 \mathrm{pmol}$ of free $\left.\mathrm{CN}-{ }^{58} \mathrm{Co}\right] \mathrm{Cbl}$. 
TABLE II

Gastrointestinal Absorption and Ileal Content of Cbl Analogues 24 h after the Simultaneous Oral Administration of $5 \mathrm{pmol}$ of $\left.\mathrm{CN}-{ }^{[57} \mathrm{Co}\right]$ Analogue and $5 \mathrm{pmol}$ of $\mathrm{CN}-\left[{ }^{58} \mathrm{Co}\right] \mathrm{Cbl}$

\begin{tabular}{|c|c|c|c|}
\hline \multirow[b]{2}{*}{ Analogue } & \multirow{2}{*}{$\begin{array}{c}K_{A} \mathrm{CN} \text {-analogue/ } \\
K_{1} \mathrm{CN}-\mathrm{Cbl}\end{array}$} & \multicolumn{2}{|c|}{$\begin{array}{c}{\left[^{\left.{ }^{77} \mathrm{Co}\right] \text { analogue } /}\right.} \\
{\left[{ }^{88} \mathrm{Co}\right] \mathrm{Cbl}^{*}}\end{array}$} \\
\hline & & $\begin{array}{l}\text { Absorp- } \\
\text { tiont }\end{array}$ & Ileum \\
\hline $\mathrm{CN}-\mathrm{Cbl}[\mathrm{b}-\mathrm{OH}]$ & 0.0006 & 0.02 & 0.12 \\
\hline $\mathrm{CN}-\mathrm{Cbl}[\mathrm{d}-\mathrm{OH}]$ & 0.3 & 0.46 & 1.02 \\
\hline $\mathrm{CN}-\mathrm{Cbl}[\mathrm{e}-\mathrm{OH}]$ & 0.004 & 0.10 & 0.22 \\
\hline $\mathrm{CN}-\mathrm{Cbl}[\mathrm{bde}-\mathrm{OH}]$ & 0.000006 & 0.06 & 0.07 \\
\hline CN-Cbl[13-epi] & 0.8 & 0.90 & 1.31 \\
\hline $\mathrm{CN}-\mathrm{Cbl} \S$ & 0.9 & 0.91 & 0.93 \\
\hline$\left[5,6, \mathrm{Cl}_{2} \mathrm{BZA}\right] \mathrm{CN}-\mathrm{Cba}$ & 1.0 & 0.49 & 1.11 \\
\hline$[\mathrm{NZA}] \mathrm{CN}-\mathrm{Cba}$ & 0.05 & 0.48 & 0.52 \\
\hline$[5(6)-\mathrm{MeBZA}] \mathrm{CN}-\mathrm{Cba}$ & 0.8 & 0.57 & 1.34 \\
\hline$\left[5(6)-\mathrm{NO}_{2} \mathrm{BZA}\right] \mathrm{CN}-\mathrm{Cba}$ & 0.1 & 0.54 & 0.53 \\
\hline$[\mathrm{BZA}] \mathrm{CN}-\mathrm{Cba}$ & 1.0 & 0.15 & 2.72 \\
\hline [2-MeAde]CN-Cba & 0.0006 & 0.09 & 0.11 \\
\hline$[$ Ade $] \mathrm{CN}-\mathrm{Cba}$ & 0.003 & 0.13 & 0.21 \\
\hline$\left[3,5,6-\mathrm{Me}_{3} \mathrm{BZA}\right](\mathrm{CN}, \mathrm{OH}) \mathrm{Cba}$ & 0.0007 & 0.08 & 0.27 \\
\hline$[\mathrm{CN}, \mathrm{OH}] \mathrm{Cbi}$ & 0.00006 & 0.02 & 0.37 \\
\hline
\end{tabular}

* Ratio represents the percent of administered $\left[{ }^{[57} \mathrm{Co}\right]$ analogue divided by the percent of administered $\left[{ }^{58} \mathrm{Co}\right] \mathrm{Cbl}$. $\$$ Based on the content of kidney, liver, heart, and lung; values of $\left.{ }^{58} \mathrm{Co}\right] \mathrm{Cbl}$ ranged from 4 to $26 \%$ in different experiments; the total absorbed based on the amount of $\left[{ }^{58} \mathrm{Co}\right] \mathrm{Cbl}$ in the colon and feces was $15-42 \%$.

$\S \mathrm{CN}-\mathrm{Cbl}$ produced biosynthetically by $P$. arabinosum.

their oral administration to rabbits. Those analogues with relatively low affinities for IF (i.e. $K_{A}$ analogue/ $K_{A} \mathrm{Cbl}<0.01$ ), were poorly absorbed and accumulated in the ileum to only a minor degree. Analogues with relatively high affinities for IF were also absorbed less well than native $\mathrm{Cbl}$. Ileal retention was greater for these analogues than for the analogues with low affinities for IF and in many cases ileal retention was greater than that observed with native $\mathrm{Cbl}$. These observations indicate that a high affinity for IF is a necessary condition for $\mathrm{Cbl}$ analogue absorption but that this is not a sufficient condition since an ileal mechanism exists, which has a structural specificity distinct from that of $\mathrm{IF}$, and results in ileal retention and the failure of many $\mathrm{Cbl}$ analogues to enter the portal blood.

Plasma transport and tissue uptake of $\mathrm{CN}-\mathrm{Cbl}$ and CN-Cbl analogues mediated by TC II. Previous studies (7) have demonstrated that the TC II-CN-Cbl complex is cleared from rabbit plasma by a variety of tissues with a $t_{\frac{1}{2}}$ of $\cong 90 \mathrm{~min}$. Some Cbl molecules are retained by cells and become bound to Cbldependent enzymes whereas other $\mathrm{Cbl}$ molecules reappear in the plasma beginning $\cong 1 \mathrm{~h}$ after uptake. In the present study 5 pmol of $\mathrm{CN}-\left[{ }^{57} \mathrm{Co}\right]$ analogue and 5 pmol of $\mathrm{CN}-\left[{ }^{58} \mathrm{Co}\right] \mathrm{Cbl}$ were incubated with excess rabbit TC II and injected together intravenously into rabbits that were killed at various times thereafter. The results obtained with [Ade]CN-Cba are shown in Fig. 4. The $1-\mathrm{h}$ data indicate that this analogue was cleared from plasma with a rate and tissue distribution that were very similar to those of native Cbl. The fact that the plasma and tissue levels of this analogue were slightly less than those of native $\mathrm{Cbl}$ at $1 \mathrm{~h}$, and the fact that urinary excretion was slightly greater, may be due to the fact that the

$$
\mathbb{Q T C I I - ( A d o ) C N}\left[{ }^{57} \mathrm{Co}\right] \mathrm{Cbo} \quad \mathrm{TCII}-\mathrm{CN}\left[{ }^{58} \mathrm{Co}\right] \mathrm{Cbl}
$$
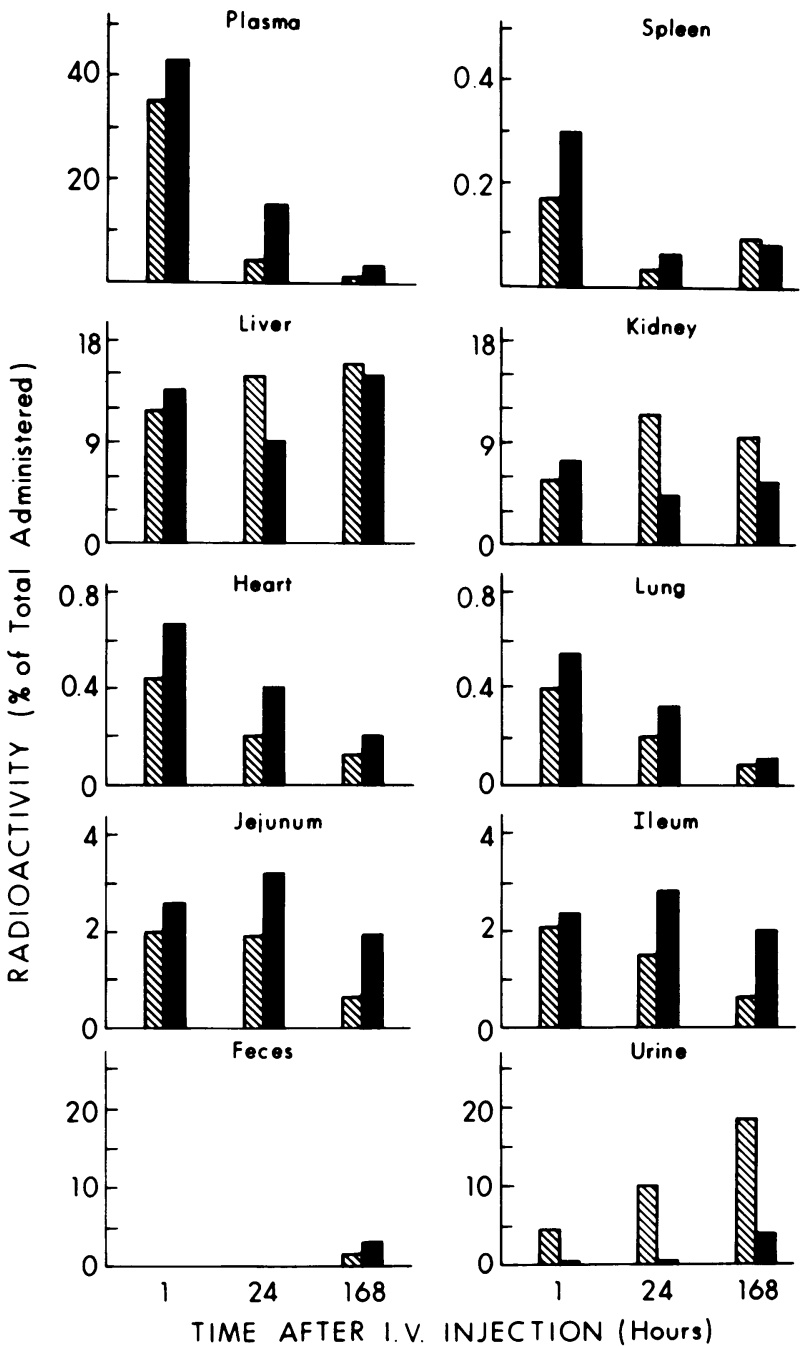

FIgURE 4 Tissue distribution of radioactivity 1,24 , and $168 \mathrm{~h}$ after the simultaneous intravenous injection of $5 \mathrm{pmol}$ of [Ade]CN- $\left[{ }^{57} \mathrm{Co}\right] \mathrm{Cba}$ and $5 \mathrm{pmol}$ of $\mathrm{CN}-\left[{ }^{58} \mathrm{Co}\right] \mathrm{Cbl}$ each bound to rabbit TC II. 
affinity of this analogue for TC II is slightly less than that of native Cbl. Previous studies (3) have shown that unbound $\mathrm{Cbl}$ is cleared rapidly from plasma by the kidney by glomerular filtration. At later time periods after injection [Ade]CN-Cba was still widely distributed although its distribution differed somewhat from that of native $\mathrm{Cbl}$. These differences suggest that tissues differ in their ability to retain and/or excrete [Ade] Cbl relative to native $\mathrm{Cbl}$.

Table III contains some of the data obtained with all of the analogues studied in this manner. Those analogues with relatively low affinities for TC II (i.e. $K_{A}$ analogue $\left./ K_{A} \mathrm{Cbl}<0.01\right)$ were taken up by tissues to a lesser extent than native $\mathrm{Cbl}$ and $20-70 \%$ of these analogues were excreted in the urine in the first few hours after their intravenous injection. All of the analogues with relatively high affinities for TC II were cleared from plasma with a rate and early tissue distribution that were very similar to those of native $\mathrm{Cbl}$. At later time periods all of the analogues remained widely distributed although in many cases their distribution differed from that of native $\mathrm{Cbl}$. $\left[5,6-\mathrm{Cl}_{2} \mathrm{BZA}\right] \mathrm{CN}-\mathrm{Cba}$ was unusual in that levels of this analogue relative to native $\mathrm{Cbl}$ decreased with time in all of the tissues studied. This observation may be due to the fact that this analogue is excreted into the bile at a much faster rate than native $\mathrm{Cbl}$ or any of the other $\mathrm{Cbl}$ analogues (see below).

These studies indicate that binding to TC II with high affinity is a necessary and sufficient condition for the cellular uptake of $\mathrm{Cbl}$ analogues. This is not surprising since previous studies $(7,8,10)$ have shown that both holo-TC II and apo-TC II bind to the same cell surface receptors and enter cells intact, thus indicating that the structure of the $\mathrm{Cbl}$ molecule is not important in this process. Our studies indicate that the structure of the $\mathrm{Cbl}$ molecule does play an important role, however, in the process by which $\mathrm{Cbl}$ is excreted from cells and/or in the process by which $\mathrm{Cbl}$ becomes bound to the two Cbl-dependent enzymes and retained intracellularly.

Plasma transport and hepatic uptake of $\mathrm{CN}-\mathrm{Cbl}$ and $\mathrm{CN}-\mathrm{Cbl}$ analogues mediated by GRP. Previous studies $(12,16)$ have demonstrated that the GRP-CNCbl complex is cleared from rabbit plasma exclusively by hepatocytes with a $t_{1}$ of $<5 \mathrm{~min}$. Approximately $10-20 \%$ of the GRP-CN-Cbl molecules are excreted intact into the bile during the first hour after uptake. Approximately $20 \%$ of the Cbl molecules become bound to Cbl-dependent enzymes and are retained intracellularly, whereas the remaining $60-70 \%$ of the $\mathrm{Cbl}$ molecules is excreted into the plasma with a $t_{1}$ of $1 \mathrm{~h}$ where they are present bound to TC II and are subsequently taken up by tissues throughout the body. In the present study, $5 \mathrm{pmol}$ of $\mathrm{CN}-\left[{ }^{57} \mathrm{Co}\right]$ analogue and $5 \mathrm{pmol}$ of $\mathrm{CN}-\left[{ }^{57} \mathrm{Co}\right] \mathrm{Cbl}$ were incubated with excess human GRP and injected together intravenously into rabbits that were sacrificed at various times there-

TABLE III

Distribution of $\mathrm{CN}-\left[{ }^{57} \mathrm{Co}\right] \mathrm{Cbl}$ Analogue and $\mathrm{CN}-\left[{ }^{58} \mathrm{Co}\right] \mathrm{Cbl}$ in Liver and Kidney 2 and $24 \mathrm{~h}$ after the Simultaneous Injection of 5 pmol of Each Bound to Rabbit TC II

\begin{tabular}{|c|c|c|c|c|c|}
\hline \multirow[b]{3}{*}{ Analogue } & \multirow{3}{*}{$\frac{K_{\boldsymbol{A}} \mathrm{CN} \text {-analogue } / \mathrm{K}_{\mathbf{A}} \mathrm{CN}-\mathrm{Cb}}{\text { Rabbit TC II }}$} & \multicolumn{4}{|c|}{$\left[{ }^{37} \mathrm{Co}\right] \mathrm{Cbl}$ analogue/[ $\left.{ }^{58} \mathrm{Co}\right] \mathrm{Cbl}$} \\
\hline & & \multicolumn{2}{|c|}{$2 \mathrm{~h}$} & \multicolumn{2}{|c|}{$24 \mathrm{~h}$} \\
\hline & & Liver & Kidney & Liver & Kidney \\
\hline $\mathrm{CN}-\mathrm{Cbl}[\mathrm{b}-\mathrm{OH}]$ & 0.01 & 0.5 & 0.6 & 0.9 & 1.5 \\
\hline $\mathrm{CN}-\mathrm{Cbl}[\mathrm{d}-\mathrm{OH}]$ & 0.3 & 0.7 & 0.9 & 1.0 & 1.2 \\
\hline $\mathrm{CN}-\mathrm{Cbl}[\mathrm{e}-\mathrm{OH}]$ & 0.3 & 1.0 & 0.9 & 0.9 & 1.6 \\
\hline $\mathrm{CN}-\mathrm{Cbl}[\mathrm{bde}-\mathrm{OH}]$ & 0.00009 & 0.2 & 0.3 & 0.2 & 0.1 \\
\hline CN-Cbl[13-epi] & 0.8 & 1.1 & 0.9 & 1.0 & 1.6 \\
\hline $\mathrm{CN}-\mathrm{Cbl}^{*}$ & 0.9 & 1.0 & 1.1 & 1.1 & 1.0 \\
\hline$\left[5,6-\mathrm{Cl}_{2} \mathrm{BZA}\right] \mathrm{CN}-\mathrm{Cba}$ & 1.0 & 1.0 & 0.9 & 0.4 & 0.5 \\
\hline [NZA]CN-Cba & 0.8 & 1.0 & 1.1 & 1.3 & 1.4 \\
\hline [5(6)-MeBZA $] \mathrm{CN}-\mathrm{Cba}$ & 0.9 & 0.9 & 1.0 & 1.6 & 1.4 \\
\hline$\left[5(6)-\mathrm{NO}_{2} \mathrm{BZA}\right] \mathrm{CN}-\mathrm{Cba}$ & 0.6 & 1.2 & 0.9 & 1.1 & 1.0 \\
\hline [BZA]CN-Cba & 1.0 & 1.0 & 1.0 & 1.6 & 3.6 \\
\hline [2-MeAde]CN-Cba & 0.3 & 1.1 & 1.1 & 3.5 & 1.2 \\
\hline [Ade]CN-Cba & 0.4 & 0.9 & 0.8 & 1.7 & 2.5 \\
\hline$\left[3,5,6-\mathrm{Me}_{3} \mathrm{BZA}\right](\mathrm{CN}, \mathrm{OH}) \mathrm{Cba}$ & 0.0008 & 0.8 & 0.3 & 0.5 & 0.3 \\
\hline$[\mathrm{CN}, \mathrm{OH}] \mathrm{Cbi}$ & 0.0003 & 0.4 & 0.3 & 1.3 & 0.2 \\
\hline
\end{tabular}

The data are expressed as the ratio of the percent of the total administered $\mathrm{CN}-\left[{ }^{57} \mathrm{Co}\right] \mathrm{Cbl}$ analogue to percent of total administered $\mathrm{CN}-\left[{ }^{58} \mathrm{Co}\right] \mathrm{Cbl}$.

* CN-Cbl produced biosynthetically with $P$. arabinosum. 
after. Similar experiments performed with rabbit GRP gave identical results.

All of the analogues were cleared rapidly from plasma by the liver which contained $>95 \%$ of each $\mathrm{CN}-\left[{ }^{57} \mathrm{Co}\right]$ analogue and $\mathrm{CN}-\left[{ }^{58} \mathrm{Co}\right] \mathrm{Cbl}$ within $10 \mathrm{~min}$ after injection. Analyses of small intestinal contents, and in some cases bile obtained by bile duct cannulation, indicated that the early (first $60 \mathrm{~min}$ ) biliary excretion, which ranged from 10 to $25 \%$ of the administered radioactivity in individual rabbits, was the same as $\mathrm{CN}-\mathrm{Cbl}$ for each of the $\mathrm{Cbl}$ analogues. The same appeared to be true for late $(60-240 \mathrm{~min})$ biliary excretion which represented $5-10 \%$ of the administered radioactivity. An exception was [5,6$\left.\mathrm{Cl}_{2} \mathrm{BZA}\right] \mathrm{CN}-\mathrm{Cba}$ which had a late biliary excretion that was three- to fivefold greater than that of $\mathrm{CN}-\mathrm{Cbl}$. This difference was observed repeatedly. Analyses of bile employing gel filtration (14) revealed that similar amounts of $\left[5,6-\mathrm{Cl}_{2} \mathrm{BZA}\right] \mathrm{Cba}$ and $\mathrm{Cbl}$ were present bound to GRP in early bile fractions and that all of the excess $\left[5,6-\mathrm{Cl}_{2} \mathrm{BZA}\right] \mathrm{Cba}$ in the late bile fractions was present either as free $\left[5,6-\mathrm{Cl}_{2} \mathrm{BZA}\right] \mathrm{Cba}$ or, to a lesser extent, bound to TC II.

In many cases the rate at which $\mathrm{Cbl}$ analogues were excreted into the plasma after their initial hepatic uptakes were much slower than that of native $\mathrm{Cbl}$. This is illustrated in Fig. 5 which contains the tissue

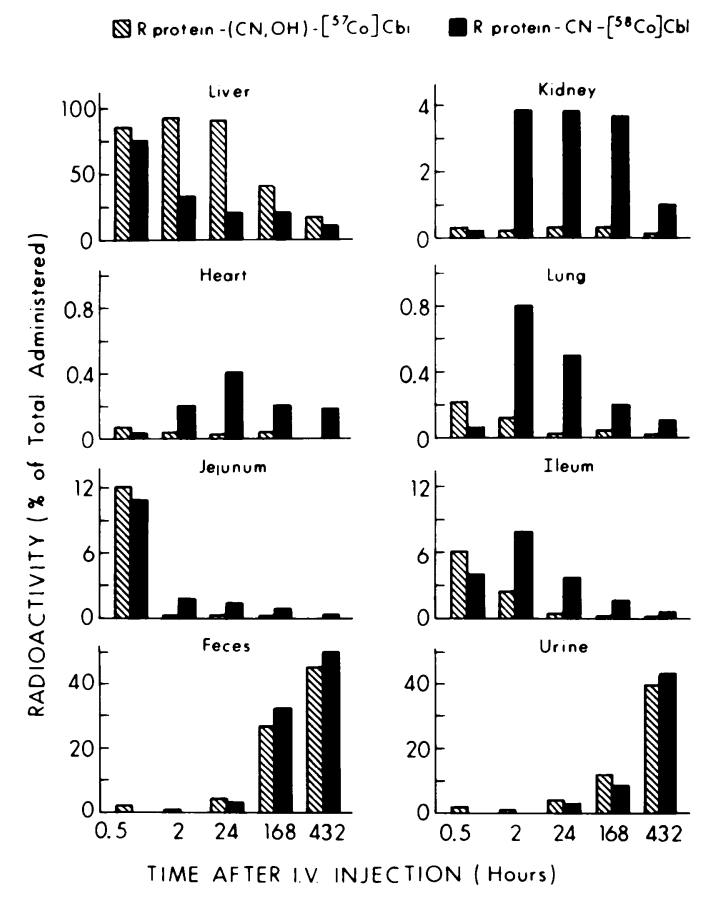

FIGURE 5 Tissue distribution of radioactivity $0.5-432 \mathrm{~h}$ after the simultaneous intravenous injection of $5 \mathrm{pmol}$ of $[\mathrm{CN}, \mathrm{OH}]$ $\left[{ }^{57} \mathrm{Co}\right] \mathrm{Cbi}$ and $5 \mathrm{pmol}$ of $\mathrm{CN}-\left[{ }^{58} \mathrm{Co}\right] \mathrm{Cbl}$ each bound to human GRP.

\section{TABLE IV}

The Rate of Hepatic Release into Plasma of Cbl Analogues after Simultaneous Intravenous Administration of $5 \mathrm{pmol}$ of $\mathrm{CN}-\left[{ }^{57} \mathrm{Co}\right]$ Analogue and $5 \mathrm{pmol}$ of $\mathrm{CN}-\left[{ }^{58} \mathrm{Co}\right] \mathrm{Cbl}$ Each Bound to Human GRP

\begin{tabular}{lr}
\hline \multicolumn{1}{c}{ Analogue } & Hepatic releas \\
& $h$ \\
$\mathrm{CN}-\mathrm{Cbl}[\mathrm{b}-\mathrm{OH}]$ & 20 \\
$\mathrm{CN}-\mathrm{Cbl}[\mathrm{d}-\mathrm{OH}]$ & 1 \\
$\mathrm{CN}-\mathrm{Cbl}[\mathrm{e}-\mathrm{OH}]$ & 1 \\
$\mathrm{CN}-\mathrm{Cbl}[\mathrm{bde}-\mathrm{OH}]$ & 20 \\
$\mathrm{CN}-\mathrm{Cbl}[13-\mathrm{epi}]$ & 1 \\
$\mathrm{CN}-\mathrm{Cbl}$ t & 1 \\
{$\left[5,6-\mathrm{Cl}{ }_{2} \mathrm{BZA}\right] \mathrm{CN}-\mathrm{Cba}$} & 1 \\
{$[\mathrm{NZA}] \mathrm{CN}-\mathrm{Cba}$} & 1 \\
{$[5(6)-\mathrm{MeBZA}] \mathrm{CN}-\mathrm{Cba}$} & 20 \\
{$\left[5(6)-\mathrm{NO}{ }_{2} \mathrm{BZA}\right] \mathrm{CN}-\mathrm{Cba}$} & 4 \\
{$[\mathrm{BZA}] \mathrm{CN}-\mathrm{Cba}$} & $>150$ \\
{$[2-\mathrm{MeAde}] \mathrm{CN}-\mathrm{Cba}$} & 100 \\
{$[\mathrm{Ade}] \mathrm{CN}-\mathrm{Cba}$} & $>150$ \\
{$\left[3,5,6-\mathrm{Me}{ }_{3} \mathrm{BZA}\right](\mathrm{CN}, \mathrm{OH}) \mathrm{Cba}$} & $>150$ \\
{$[\mathrm{CN}, \mathrm{OH}] \mathrm{Cbi}$} & $>150$
\end{tabular}

* In all experiments $>95 \%$ of the $\mathrm{CN}$ analogue and $\mathrm{CN}-\mathrm{Cbl}$ was present in the liver $10 \mathrm{~min}$ after injection. The $t_{i}$ was the time when $\cong 50 \%$ of the analogue remained in the liver. This value was 1 for $\mathrm{CN}-\mathrm{Cbl}$.

$\ddagger \mathrm{CN}$-Cbl produced biosynthetically with P. arabinosum.

distribution of $[\mathrm{CN}, \mathrm{OH}]-\left[{ }^{57} \mathrm{Co}\right] \mathrm{Cbi}$ and $\mathrm{CN}-\left[{ }^{58} \mathrm{Co}\right] \mathrm{Cbl}$ at various times after their simultaneous intravenous injection into rabbits. At $0.5 \mathrm{~h}$ after injection most of the analogue and $\mathrm{Cbl}$ were present in the liver except for the amounts that enter the jejunum via the bile. By $2 \mathrm{~h}$ after injection more than half of the native $\left[{ }^{58} \mathrm{Co}\right] \mathrm{Cbl}$ had left the liver and had a wide tissue distribution similar to that observed when $\mathrm{Cbl}$ is injected bound to TC II. In contrast, $\left[{ }^{57} \mathrm{Co}\right] \mathrm{Cbi}$ was retained by the liver and $>150 \mathrm{~h}$ were required before the hepatic level of this analogue decreased to one-half of its initial level. Experiments of this kind were performed with each $\mathrm{Cbl}$ analogue and utilized to estimate the rate at which they were released into plasma from the liver. The values obtained are presented in Table IV and indicate that alterations in the nucleotide moiety of $\mathrm{Cbl}$ effect the greatest reductions in its rate of release into plasma from the liver. Analyses of hepatic homogenates by gel filtration (12) suggested that all of the GRP-Cbl analogues were converted to free $\mathrm{Cbl}$ analogue by $45 \mathrm{~min}$ after injection and that most of each $\mathrm{Cbl}$ analogue remained in unbound form at later time periods. These observations indicate that hepatic retention of $\mathrm{Cbl}$ analogues is not due to an inability to liberate $\mathrm{Cbl}$ analogues from GRP or to excessive binding of $\mathrm{Cbl}$ analogues by intracellular Cbl-dependent enzymes although they 
do not rule out the possibility that they are bound by a different intracellular CblBP that is denatured, or releases $\mathrm{Cbl}$, during the preparation of tissue for gel filtration.

A comparison between Tables IV and I shows that the mechanism that effects the hepatic release of Cbl into plasma has a structural specificity that is distinct from those of binding to IF, TC II, and GRP. Preliminary studies also indicate that this mechanism is saturable with a maximal release rate of $2,000 \mathrm{ng}$ of $\mathrm{Cbl}$ per $\mathrm{h}$, and that $\mathrm{Cbl}$ analogues compete with native $\mathrm{Cbl}$ for release. ${ }^{3}$

The studies in this section indicate that binding to GRP with high affinity is a necessary and sufficient condition for the hepatocyte uptake of $\mathrm{Cbl}$ analogues. This is not unexpected since previous studies (14) have shown that both holo-GRP and apo-GRP bind to the same cell surface receptors and enter hepatocytes intact, thus indicating that the structure of the $\mathrm{Cbl}$ molecule is not important in this process. The studies presented here also indicate that the structure of the Cbl molecule is unimportant in the undefined mechanism by which GRP-Cbl is excreted into the bile in intact form. The structure of the Cbl molecule is important, however, in the processes involving the plasma and late biliary excretion of $\mathrm{Cbl}$ by hepatocytes although the structural specificities of these processes differ from each other and from those of binding to IF, TC II, and GRP.

Comparison of the tissue distribution of [Ade]CNCba bound to GRP vs. that of [Ade]CN-Cba bound to TC II. The studies in the previous sections suggest that the transport and the eventual tissue distribution of $\mathrm{Cbl}$ analogues of the kind that are slowly excreted by hepatocytes might differ markedly depending upon whether their initial transport in plasma was mediated via GRP or TC II. To test this hypothesis 5 pmol of [Ade]CN- $\left[{ }^{57} \mathrm{Co}\right] \mathrm{Cba}$ bound to GRP was mixed with 5 pmol of [Ade] $\mathrm{CN}-\left[{ }^{58} \mathrm{Co}\right] \mathrm{Cba}$ bound to TC II and injected intravenously into rabbits that were killed at various times thereafter. The results of these experiments are presented in Fig. 6 and show that the long-term distribution of the analogue injected bound to GRP remains confined to the liver although the same analogue bound to TC II remains widely distributed. Despite this difference it is interesting that both forms of the analogue are excreted in the urine and feces in similar amounts and at similar rates. It is unclear how this analogue moves from the liver to the urine without being taken up by other tissues especially since rabbit plasma contains $10-20$ pmol of unsaturated TC II Cbl-binding ability per $\mathrm{ml}(7)$.

${ }^{3}$ Kolhouse, J. F., and R. H. Allen. Unpublished observations.

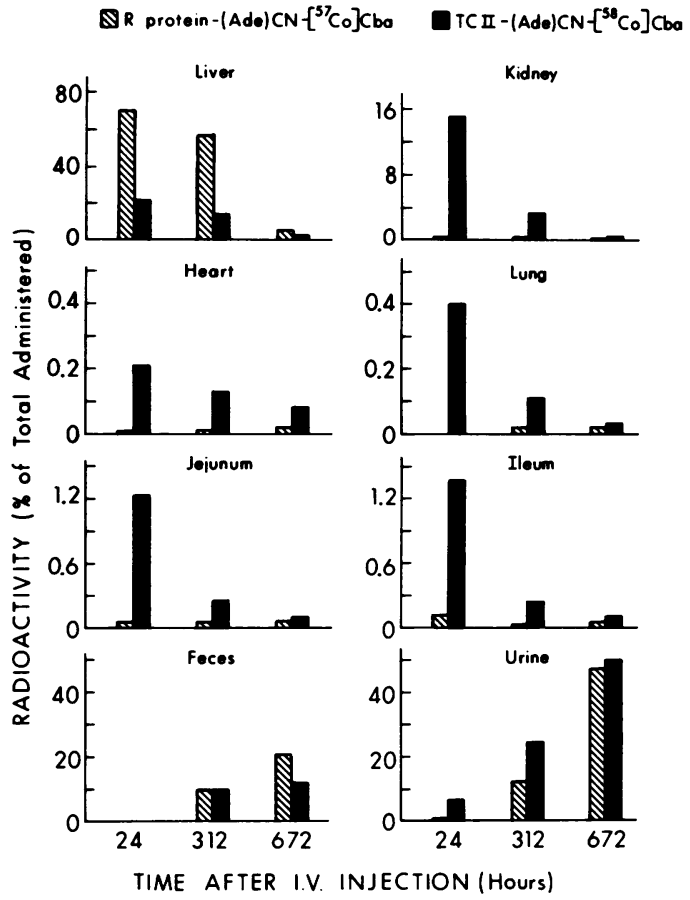

Figure 6 Tissue distribution of radioactivity 24, 312, and $672 \mathrm{~h}$ after the simultaneous intravenous injection of [Ade]CN-[ $\left.{ }^{57} \mathrm{Co}\right] \mathrm{Cba}$ bound to human GRP and $5 \mathrm{pmol}$ of [Ade] CN- $\left[{ }^{58} \mathrm{Co}\right] \mathrm{Cba}$ bound to rabbit TC II.

\section{DISCUSSION}

Microorganisms synthesize a variety of $\mathrm{Cbl}$ analogues in addition to native $\mathrm{Cbl}$ (16). Ruminants, and animals that ingest their feces, are clearly exposed to $\mathrm{Cbl}$ analogues since ruminal contents and feces contain more $\mathrm{Cbl}$ analogue than native $\mathrm{Cbl}(16)$. It appears likely that man and other animals are also exposed to $\mathrm{Cbl}$ analogues from sources that include the following: (a) $\mathrm{Cbl}$ analogue-producing bacteria that cross epithelial surfaces; $(b)$ systemic infections with $\mathrm{Cbl}$ analogue-producing bacteria; and (c) $\mathrm{Cbl}$ analogue synthesis by bacteria in food, saliva, milk, and the small intestine. Brandt et al. (32) have shown that self-filling small intestinal blind loops in dogs contain 700-6,000 times more $\mathrm{Cbl}$ analogue than native $\mathrm{Cbl}$. [Ade] Cba, $\mathrm{Cbi}$, and [2-MeAde] Cba were the most abundant $\mathrm{Cbl}$ analogues and during a 1 - to 12 -month period $\mathrm{Cbi}$, [2-MeAde]Cba, and to a lesser extent [Ade]Cba, progressively increased in the liver whereas native $\mathrm{Cbl}$ progressively decreased. Other tissues were not examined in this study.

Microorganisms often utilize $\mathrm{Cbl}$ analogues (16) and in many cases $\mathrm{Cbl}$ analogues are more active as coenzymes for their enzyme systems than is "native Cbl" (33). Several lines of evidence suggest, however, that many $\mathrm{Cbl}$ analogues are inactive and potentially toxic for animals. Coates et al. (34) have shown that a 
variety of $\mathrm{Cbl}$ analogues lack activity and in some cases inhibit the growth and development of chicks. Siddons et al. (35) have shown that the 2-methyl-2-aminopropanol analogue of $\mathrm{Cbl}$ induces a severe demyelinating disease when given to Cbl-deficient baboons. Data concerning the ability of naturally occurring $\mathrm{Cbl}$ analogues to inhibit animal Cbl-dependent enzymes are not available although Lengyel et al. (17) have shown that the coenzyme forms of [BZA]Cba and [Ade]Cba have 10- and at least 1,000-fold higher $K_{m}$ for sheep kidney methylmalonyl-CoA mutase than does the coenzyme form of native $\mathrm{Cbl}$.

The studies presented here suggest that animals contain several mechanisms that function to prevent the absorption of a number of $\mathrm{Cbl}$ analogues, including the most common naturally occurring analogues [Ade]Cba, Cbi, and [2-MeAde]Cba (16). We have confirmed and extended the studies of others (36-38) that suggested that IF is the most selective CblBP and that this selectivity prevents the absorption of many $\mathrm{Cbl}$ analogues. We have also shown that a separate ileal mechanism exists which leads to the ileal retention of $\mathrm{Cbl}$ analogues and prevents their entry into the portal blood.

The studies presented here also suggest that animals possess additional mechanisms that function to prevent the tissue dissemination of $\mathrm{Cbl}$ analogues that do gain access to the body, and that these mechanisms are also effective with respect to the most common naturally occurring $\mathrm{Cbl}$ analogues. We have shown that GRP binds a wide variety of $\mathrm{Cbl}$ analogues with high affinity. This lack of selectivity appears to enhance the antibacterial function of GRP since this protein can bind $\mathrm{Cbl}$ and $\mathrm{Cbl}$ analogues and make them unavailable for certain bacteria that require them for growth. GRP has the following characteristics that favor it over TC II in terms of competing for binding of $\mathrm{Cbl}$ analogues in vivo: ( $a$ ) GRP has a higher affinity for $\mathrm{Cbl}$ and $\mathrm{Cbl}$ analogues than TC II; $(b)$ GRP retains its high affinity over a $\mathrm{pH}$ range of $2-12$ whereas that of TC II decreases markedly below pH 5 (39) and is thus relatively ineffective in areas of necrosis or infection; and (c) GRP is located in the specific granules of granulocytes (40) from which it is released into phagosomes and also extracellularly $(41,42)$. The enhanced ability of GRP to bind $\mathrm{Cbl}$ analogues enables them to be transported exclusively to hepatocytes rather than to other tissues which may be more susceptable to their toxic effects. Our studies demonstrate that delivery to hepatocytes prevents the dissemination of many $\mathrm{Cbl}$ analogues since at least one analogue is preferentially excreted in the bile and others are retained intracellularly. The latter are eventually excreted in the urine and feces although the mechanism by which they reach the urine is not known. The fact that they do so without being bound and disseminated by TC II suggests that $\mathrm{Cbl}$ analogues may be transported from hepatocytes by some unknown mechanism or that the structures of $\mathrm{Cbl}$ analogues are altered within hepatocytes. If the latter does occur it must involve some change other than the exchange of $\mathrm{OH}$ for $\mathrm{CN}$ as the upper axial ligand since preliminary studies in our laboratory indicate that the transport and ultimate distribution of $\mathrm{OH}-\mathrm{Cbl}$ and [Ade] $\mathrm{OH}-\mathrm{Cba}$ are not markedly different from those of their $\mathrm{CN}$ forms.

The ultimate proof of our hypothesis that the mechanisms mentioned above serve important protective functions requires additional evidence that naturally occurring $\mathrm{Cbl}$ analogues can cause toxicity, and that such toxicity is associated with the abnormal presence of $\mathrm{Cbl}$ analogues in individuals defective in the mechanisms mentioned above. Little information is currently available in this regard although it is interesting that one of two brothers with a congenital absence of R-type protein, including GRP, does have a severe neurologic illness that is similar clinically to multiple sclerosis (43).

The studies presented here also support the feasability of utilizing $\mathrm{Cbl}$ analogues as antimetabolites in vivo since our data indicate that TC II is capable of binding a large number of $\mathrm{Cbl}$ analogues and transporting them to a variety of tissues. This information would be useful in evaluating $\mathrm{Cbl}$ analogues for toxicity and in studies designed to correlate such toxicity with the inhibition of individual Cbl-dependent enzymes. Studies of this kind could lead to a better understanding of the biochemical basis of the megaloblastic anemia and neurologic defects associated with Cbl deficiency, as well as to the development of a new class of chemotherapeutic agents for malignancies. Investigation of the latter possibility appears particularly interesting since several recent studies $(44,45)$ indicate that a number of malignant cell lines differ from normal cells in terms of their activities of, and/or their dependence on, the Cbl-dependent enzyme methionine synthetase which catalyzes the conversion of $N^{5}$ methyltetrahydrofolate and homocysteine to tetrahydrofolate and methionine.

\section{APPENDIX}

Measurement of the ratio of $K_{A}$ analogue to $K_{A} C b l$. The affinity of a small molecular weight inhibitor for a macromolecule relative to the affinity of a small molecular weight ligand for the same macromolecule can be expressed as the ratio of the association constant of the inhibitor $\left(K_{A} A\right)$ to the association constant of the ligand $\left(K_{A} B\right)$. In a system consisting of a small molecular weight ligand and a macromolecule to which it binds, a second compound that binds to the macromolecule at the same site and thereby inhibits binding of the first ligand is called a competitive inhibitor. This situation can be represented by the equilibria: 


$$
\begin{gathered}
A+X \stackrel{K_{A} A}{\rightleftharpoons} A X \\
B+X \stackrel{K_{A} B}{\rightleftharpoons} B X,
\end{gathered}
$$

where $A$ represents inhibitor, $B$ represents ligand and $X$ represents the macromolecule. The $K_{A}$ are:

$$
\begin{aligned}
& K_{A} A=\frac{(A X)}{(A)(X)} \\
& K_{A} B=\frac{(B X)}{(B)(X)},
\end{aligned}
$$

where $(A)$ and $(B)$ are the concentrations of free inhibitor and ligand, respectively, $(A X)$ and $(B X)$ are concentrations of bound inhibitor and ligand, respectively, and $(X)$ is the concentration of free macromolecule. The ratio is:

$$
\frac{K_{A} A}{K_{A} B}=\frac{(A X)(B)}{(A)(B X)} .
$$

Quantities $(A X)$ and $(A)$ can be determined by the following equations:

$$
\begin{aligned}
(A X) & =(X \text { total })-(B X)-(X) \\
(A) & =(A \text { total })-(A X) .
\end{aligned}
$$

By substituting Eq. 2 into Eq. 3:

$$
(A)=(A \text { total })-(X \text { total })+(B X)+(X) \text {. }
$$

Under conditions in which the concentration of ligand is in excess of the binding capacity of the macromolecule and the quantity $(X)$ is $\ll(X$ total $)$. Eqs. 2 and 4 become:

$$
\begin{aligned}
(A X) & =(X \text { total })-(B X) \\
(A) & =(A \text { total })-(X \text { total })+(B X) .
\end{aligned}
$$

By substitution of Eqs. 5 and 6 into Eq. 1:

$$
\frac{K_{A} A}{K_{A} B}=\frac{[(X \text { total })-(B X)][(B)]}{[(A \text { total })-(X \text { total })+(B X)][(B X)]} .
$$

There are three internal checks on the appropriateness of this equation for the experimental situation. First, plotting of $[(X$ total $)-(B X)][(B)]$ vs. $[(A$ total $)-(X$ total $)+(B X)]-$ $[(B X)]$ should result in a straight line. Second, this line should pass through the origin. Third, when $A$ and $B$ are the same compound, the slope, i.e., $K_{A} A$, should equal 1 .

$$
\overline{K_{A} B}
$$

\section{ACKNOWLEDGMENTS}

We would like to thank Mrs. Carol Mehlman Margolis and Ms. Elaine R. Podell for their assistance in performing this study.

This work was supported by grants AM 16668 and HL 07088 from the National Institutes of Health, and Faculty Research Award FRA-122 from the American Cancer Society.

\section{REFERENCES}

1. Kolhouse, J. F., and R. H. Allen. 1976. Mechanism of hepatocyte release of vitamin $\mathrm{B}_{12}$ into plasma. Clin. Res. 24: 312A. (Abstr.)

2. Barker, H. A. 1972 . Corrinoid-dependent enzyme reactions. Annu. Rev. Biochem. 41: 55-90.
3. Allen, R. H. 1975. Human vitamin $B_{12}$ transport proteins. In Prog. Hematol. 9: 57-84.

4. Ellenbogen, L. 1975. Absorption and transport of cobalamin. In Cobalamin. B. M. Babior, editor. John Wiley \& Sons, Inc., New York. 1st edition. 215-286.

5. Stenman, U. H. 1976. Intrinsic factor and the vitamin $B_{12}$ binding proteins. Clin. Haematol. 5: 473-495.

6. Hooper, D. C., D. H. Alpers, R. L. Burger, C. S. Mehlman, and R. H. Allen. 1973. Characterization of ileal vitamin $B_{12}$ binding using homogeneous human and hog intrinsic factors. J. Clin. Invest. 52: 3074-3083.

7. Schneider, R. J., R. L. Burger, C. S. Mehlman, and R. H. Allen. 1976. The role and fate of rabbit and human transcobalamin II in the plasma transport of vitamin $B_{12}$ in the rabbit. J. Clin. Invest. 57: 27-38.

8. Friedman, P. A., M. A. Shia, and J. K. Wallace. 1977. A saturable high affinity binding site for transcobalamin II-vitamin $B_{12}$ complexes in human placental membrane preparations. J. Clin. Invest. 59: 51-58.

9. Pletsch, Q. A., and J. W. Coffey. 1972. Properties of the proteins that bind vitamin $B_{12}$ in subcellular fractions of rat liver. Arch. Biochem. Biophys. 151: 157-167.

10. Youngdahl-Turner, P., R. H. Allen, and L. E. Rosenberg. 1977. Binding and uptake of transcobalamin II by human fibroblasts. Clin. Res. 472A. (Abstr.)

11. Rosenberg, L. E., L. Patel, and A-C Lilljequist. 1975. Absence of an intracellular cobalamin-binding protein in cultured fibroblasts from patients with defective synthesis of $5^{\prime}$-deoxyadenosylcobalamin and methylcobalamin. Proc. Natl. Acad. Sci. U. S. A. 72: 4617-4621.

12. Kolhouse, J. F., and R. H. Allen. 1977. Recognition of two intracellular cobalamin binding proteins and their identification as methylmalonyl-CoA mutase and methionine synthetase. Proc. Natl. Acad. Sci. U. S. A. 74: 921-925.

13. Mellman, I. S., P. Youngdahl-Turner, F. W. Huntington, and L. E. Rosenberg. 1977. Intracellular binding of radioactive hydroxycobalamin to cobalamin-dependent apoenzymes in rat liver. Proc. Natl. Acad. Sci. U. S. A. 74: 916-920.

14. Burger, R. L., R. J. Schneider, C. S. Mehlman, and R. H. Allen. 1975. Human plasma R-type vitamin $B_{12}$-binding proteins. II. The role of transcobalamin I, transcobalamin III and the normal granulocyte vitamin $B_{12}$-binding protein in the plasma transport of vitamin $\mathrm{B}_{12}$. J. Biol. Chem. 250: 7707-7713.

15. Ashwell, G., and A. G. Morell. 1974. The role of surface carbohydrates in the hepatic recognition and transport of circulating glycoproteins. Adv. Enzymol. 41: 99-128.

16. Smith, E. L. 1965. Vitamin $B_{12}$. John Wiley \& Sons, Inc., New York. 3rd edition.

17. Lengyel, P., R. Mazumder, and S. Ochoa. 1960. Mammalian methylmalonyl isomerase and vitamin $B_{12}$ coenzymes. Proc. Natl. Acad. Sci. U. S. A. 46: 1312-1318.

18. Hogenkamp, H. P. C. 1975. The chemistry of cobalamins and related compounds. In Cobalamin. B. M. Babior, editor. John Wiley \& Sons, Inc., New York. 1st edition. 21-73.

19. Bonnett, R., J. M. Godfrey, and V. B. Math. 1971. Cyano13-epicobalamin (Neovitamin $B_{12}$ ) and its relatives. $J$. Chem. Soc. 3736-3743.

20. Allen, R. H., and P. W. Majerus. 1972. Isolation of vitamin $B_{12}$ binding proteins using affinity chromatography. I. Preparation and properties of vitamin $B_{12}$-Sepharose. J. Biol. Chem. 247: 7695-7701.

21. Yamada, R. H., and H. P. C. Hogenkamp. 1972. The synthesis of a 5'-deoxyadenosylcobalamin-agarose adsorbent 
and its utility in the purification of ribonucleotide reductase. J. Biol. Chem. 247:6266-6270.

22. Friedrich, W., and von K. Bernhauer. 1956. Beitrage zur Chemie und Biochemie der "Cobalamine," I. Mitteil.: Über die Alkylierung von $B_{12}$-Facktor III und Vitamin $B_{12}$. Chem. Ber. 89: 2030-2044.

23. Armitage, J. B., J. R. Cannon, A. W. Johnson, L. F. J. Parker, E. L. Smith, W. H. Stafford, and A. R. Todd. 1953. Chemistry of the vitamin $B_{12}$ group. III. The course of hydrolytic degradations. J. Chem. Soc. 3849-3864.

24. Mathan, V. I., B. M. Babior, and R. M. Donaldson, Jr. 1974. Kinetics of the attachment of intrinsic factor-bound cobamides to ileal receptors. J. Clin. Invest. 54: 598-608.

25. Kolhouse, J. F., and R. H. Allen. 1977. Isolation of cobalamin and cobalamin analogs by reverse affinity chromatography. Anal. Biochem. In press.

26. Perlman, D., and J. M. Barrett. 1958. Biosynthesis of cobalamin analogs by Propionibacterium arabinosum. Can. J. Microbiol. 4: 9-15.

27. Allen, R. H., and C. S. Mehlman. 1973. Isolation of gastric vitamin $B_{12}$ binding proteins using affinity chromatography. I. Purification and properties of human intrinsic factor. J. Biol. Chem. 248: 2660-3669.

28. Burger, R. L., R. J. Schneider, C. S. Mehlman, and R. H. Allen. 1975. Human plasma R-type vitamin $B_{12}$ binding proteins. I. Isolation and characterization of transcobalamin I, transcobalamin III, and the normal granulocyte vitamin $\mathrm{B}_{12}$ binding protein. J. Biol. Chem. 250: 77007706.

29. Masson, P. L., J. F. Heremans, and E. Schonne. 1969. Lactoferrin, an iron-binding protein in neutrophilic leukocytes. J. Exp. Med. 130: 643-658.

30. Allen, R. H., and P. W. Majerus. 1972. Isolation of vitamin $B_{12}$-binding proteins using affinity chromatography. II. Purification and properties of a human granulocyte vitamin-B B $_{12}$-binding protein. J. Biol. Chem. 247: 77027708.

31. Gottlieb, C., L. Kam-Seng, L. R. Wasserman, and V. Herbert. 1965. Rapid charcoal assay for intrinsic factor (IF) gastric juice unsaturated $B_{12}$ binding capacity, antibody to IF and serum unsaturated $B_{12}$ binding capacity. Blood 25: 875-884.

32. Brandt, L. J., L. H. Bernstein, G. Efron, and A. Wagle. 1975. Vitamin $B_{12}$ analog production in the experimental blind loop. Gastroenterology. 68(A-6): 863.

33. Barker, H. A., R. D. Smyth, H. Weissbach, J. I. Toohey, J. N. Ladd, and B. E. Volcani. 1960. Isolation and properties of crystalline cobamide coenzymes containing benzimidazole or 5,6-dimethylbenzimidazole. J. Biol. Chem. 235: 480-488.
34. Coates, M. E., M. K. Davies, and G. F. Harrison. 1960. Anti-vitamin $B_{12}$ activity for the growing chick and developing chick embryo of some analogs of cyanocobalamin. Arch. Biochem. Biophys. 87: 93-99.

35. Siddons, R. C., J. A. Spence, and A. D. Dayan. 1975. Experimental vitamin $\mathrm{B}_{12}$ deficiency in the baboon. Adv. Neurol. 10: 239-252.

36. Gottlieb, C. W., F. P. Retief, and V. Herbert. 1967. Blockade of vitamin $B_{12}$-binding sites in gastric juice, serum and saliva by analogues and derivatives of vitamin $B_{12}$ and by antibody to intrinsic factor. Biochim. Biophys. Acta. 141: 560-572.

37. Hippe, E., E. Haber, and H. Olesen. 1971. Nature of vitamin $B_{12}$ binding. II. Steric orientation of vitamin $B_{12}$ on binding and number of combining sites of human instrinsic factor and transcobalamins. Biochim. Biophys. Acta. 243: 75-82.

38. Bunge, M. B., L. L. Schloesser, and R. F. Schilling. 1956. Intrinsic factor studies. IV. Selective absorption and binding of cyanocobalamin by gastric juice in the presence of excess pseudo-vitamin $B_{12}$ or 5,6-dimethylbenzimidazole. J. Lab. Clin. Med. 48: 735-744.

39. Hippe, E., and H. Olesen. 1971. Nature of vitamin $B_{12}$ binding. III. Thermodynamics of binding to human intrinsic factor and transcobalamins. Biochim. Biophys. Acta. 243: 83-89.

40. Kane, S. P., and T. J. Peters. 1975. Analytical subcellular fractionation of human granulocytes with reference to the localization of vitamin $\mathrm{B}_{12}$ binding proteins. Clin. Sci. Mol. Med. 49: 171-182.

41. Corcino, J., S. Krauss, S. Waxman, and V. Herbert. 1970. Release of vitamin $\mathrm{B}_{12}$-binding protein by human leukocytes in vitro. J. Clin. Invest. 49: 2250-2255.

42. Scott, J. M., F. J. Bloomfield, R. Stebbins, and V. Herbert. 1974. Studies on the derivation of transcobalamin III from granulocytes. Enhancement by lithium and elimination by fluoride of in vitro increments in vitamin $B_{12^{-}}$ binding capacity. J. Clin. Invest. 53: 228-239.

43. Carmel, R., and V. Herbert. 1969. Deficiency of vitamin $\mathrm{B}_{12}$-binding alpha globulin in two brothers. Blood. 33: 1 12.

44. Halpern, R. M., B. C. Halpern, B. R. Clark, H. Ashe, D. N. Hardy, P. Y. Jenkinson, S-C. Chou, and R. A. Smith. 1975. New approach to antifolate treatment of certain cancers as demonstrated in tissue culture. Proc. Natl. Acad. Sci. U. S. A. 72: 4018-4022.

45. Hoffman, R. M., and R. W. Erbe. 1976. High in vivo rates of methionine biosynthesis in transformed human and malignant rat cells auxotrophic for methionine. Proc. Natl. Acad. Sci. U. S. A. 73: 1523-1527. 